Research Article

\title{
Stability Analysis of Surrounding Rock of Large Section Ultradeep Shaft Wall
}

\author{
Cheng Li $\mathbb{D}^{1,2}$ Wang Chunlong, ${ }^{1,2}$ Wang Xi, ${ }^{1,2}$ and Chen Kexu ${ }^{1,2}$ \\ ${ }^{1}$ Deep Mining Laboratory of Shandong Gold Group Co., Ltd., Yantai 264000, China \\ ${ }^{2}$ Shandong Key Laboratory of Deep-sea and Deep-earth Metallic Mineral Intelligent Mining, Yantai 264000, China \\ Correspondence should be addressed to Cheng Li; chengli@sd-gold.com
}

Received 14 August 2021; Revised 9 September 2021; Accepted 18 September 2021; Published 8 October 2021

Academic Editor: Zhengyang Song

Copyright (c) 2021 Cheng Li et al. This is an open access article distributed under the Creative Commons Attribution License, which permits unrestricted use, distribution, and reproduction in any medium, provided the original work is properly cited.

In order to study the stability of deep surrounding rock during the excavation of new main shaft in Xincheng gold mine, a construction method suitable for large section ultradeep shaft is proposed. A series of analyses were carried out in this study, including the in situ stress test, stress response of surrounding rock disturbance, deformation and failure characteristics, and numerical simulation. Based on the above analysis, the stability control method of surrounding rock in the process of deep excavation of the new main shaft is proposed. The results show that (1) the maximum principal stress of deep surrounding rock of new main shaft is horizontal stress, and the surrounding rock of the shaft has strong rock burst tendency after excavation; (2) the influence range of the deep shaft excavation disturbance is 6.4 times the shaft radius, in which the temporary support should be strengthened to avoid the influence of excavation disturbance on the stability of shaft wall rock; (3) the failure shape of surrounding rock of the deep shaft excavation was "ear" failure, and the failure depth was not more than $2.5 \mathrm{~m}$; (4) after replacing the original "one-excavation and one-masonry" construction with "three-excavation and one-masonry" construction, the temporary support span of the main shaft was adjusted to $12 \mathrm{~m}$, which can make the subsequent concrete shaft wall in the state of "no pressure bearing or slow low pressure bearing," and the lining compressive safety coefficient was increased to 1.98 , which meets the safety requirements.

\section{Introduction}

With the gradual increase of mining depth of underground metal, the construction of some over kilometer deep shafts has been completed. For example, the depth of the auxiliary well of Benxi Sisanling iron mine is $1497.7 \mathrm{~m} \mathrm{[1]}$, and the 3\# shaft depth of Huize lead zinc mine in Yunnan is $1526 \mathrm{~m}$. [2]. The experience at home and abroad and in Jiaodong area shows that, with the increase of shaft excavation depth, the instability of surrounding rock and the cracking and failure of shaft lining structure are prone to occurring under the influence of deep high stress [2-5]. At the same time, the rock burst disasters [6-11] caused by deep shaft excavation will lead to a series of problems, such as the deterioration of shaft construction environment and the sharp increase of production cost, which have brought severe challenges to the construction of deep shaft.
At present, scholars at home and abroad have carried out rich research on the stability control of shaft wall surrounding rock and have also achieved some scientific research results. For example, Ju et al. [12] and others designed and formulated the technical scheme of pressure relief casing method to prevent and strengthen shaft failure according to the shaft failure mechanism; Zhou et al. [13] and others studied the contribution of surrounding rock to shaft wall bearing capacity from three aspects: equal failure, equal wall thickness, and overall data statistics; Li and Wang [14] and others carried out research on borehole pressure relief technology for surrounding rock of high stress shaft under different pressure relief hole layout conditions and proposed that flexible initial support + cast in situ concrete shaft wall support combined with borehole pressure relief technology can effectively ensure the safety and stability of shaft wall under high stress conditions. Aiming at the problem of shaft 
surrounding rock support in a deep large fault fracture area, Sun et al. [15] and others introduced the idea of "high resistance and yield pressure," applied the convergence constraint method to the design of deep buried shaft support structure and the stability evaluation of the support system, and achieved ideal results in field application. Relying on the mixed shaft project of Sishanling iron mine, Bian [16] proposed a complete set of construction technologies for large-diameter and ultradeep shaft and successfully completed the construction of the first large-diameter and ultradeep shaft in China. In general, the research on shaft construction and shaft wall surrounding rock control mainly focuses on shafts with a net diameter of $5 \sim 6 \mathrm{~m}$ and a depth of less than $1500 \mathrm{~m}$. There is less research on the construction of large section and ultradeep shafts with a diameter of more than $7 \mathrm{~m}$ and a design depth of more than $1500 \mathrm{~m}$. Therefore, the existing results are difficult to guide engineering practice. At the same time, during the excavation of large section ultradeep shaft, the surrounding rock of shaft wall is affected by complex geological structural conditions such as high stress, which will lead to a large deformation of surrounding rock and increase the risk of rock burst. The traditional construction technology and support methods can not meet the safety needs.

In view of this, taking the new main shaft construction project of Xincheng gold mine as the background, this paper discusses the stability control method of deep surrounding rock by studying the response characteristics of disturbed stress and deformation failure characteristics, in order to provide a technical reference for similar engineering practice.

\section{Project Overview}

Xincheng gold mine is located in Jincheng town, Laizhou city, Shandong province. The occurrence conditions of the ore body are complex. It is a typical altered rock type gold deposit. After more than 40 years of continuous mining, it has been mined to $-1030 \mathrm{~m}$ level. With the continuous promotion of deep development projects, the original main shaft can no longer meet the needs of production scale. Therefore, a new main shaft is designed and constructed in the mine. The design diameter of the new main shaft is $7.5 \mathrm{~m}$ and the design depth is $1527 \mathrm{~m}$. After construction, it will become the deepest shaft in China. Except that the shaft neck section is supported by reinforced concrete, other parts of the shaft are supported by plain concrete. The thickness of concrete above $-622 \mathrm{~m}$ level is $300 \mathrm{~mm}$, the thickness of concrete below $-622 \mathrm{~m}$ level is $400 \mathrm{~mm}$, and the concrete strength grade is C25. The short section excavation and masonry mixed construction method of "one-excavation and one-masonry" normal cycle with a section height of $4 \mathrm{~m}$ was adopted. However, after the construction reached the level of $-1000 \mathrm{~m}$, the surrounding rock pressure of the shaft wall was intense, the shaft wall concrete in some areas even fell off, and the on-site construction efficiency was significantly reduced. Therefore, it is necessary to deeply analyze the disturbance stress response characteristics and deformation and failure characteristics of the deep surrounding rock of the new main shaft, so as to provide a scientific basis for the stability control of the surrounding rock during the deep excavation of large section and ultradeep shaft.

\section{Analysis of Rock Burst Tendency and Influence Range of Disturbance Stress in Deep Surrounding Rock}

3.1. Analysis of In Situ Stress and Rockburst Tendency. To study the in situ stress distribution characteristics of the surrounding rock in the deep part of the shaft, the engineering geological borehole JCK-1 (hole depth $-930 \mathrm{~m}$ to $-1450 \mathrm{~m}$ ) parallel to the shaft was used to carry out in situ stress measurement. Six cores with different depths of $-950 \mathrm{~m},-1050 \mathrm{~m},-1150 \mathrm{~m},-1250 \mathrm{~m},-1350 \mathrm{~m}$, and $-1450 \mathrm{~m}$ were selected for in situ stress measurement based on rock acoustic emission Kaiser effect method. Some test pieces are shown in Figure 1, and acoustic emission test equipment and signal acquisition system are shown in Figure 2.

Reference [8] gives the maximum horizontal principal stress, minimum horizontal principal stress, and maximum horizontal principal stress direction of in situ stress of rock mass at each measuring point, and the results are shown in Table 1 .

According to Table 1, the distribution of deep in situ stress field is linearly fitted, and the result is shown in Figure 3.

Based on this, the distribution laws of in situ stress in this area are obtained as follows:

(1) In situ stress is mainly horizontal tectonic stress, and the maximum principal stress is horizontal stress. The maximum horizontal principal stress and vertical principal stress increase with the increase of hole depth.

(2) The azimuth consistency of the maximum horizontal principal stress at different depths is well, all in the direction of NWW $\sim \mathrm{SEE}$, distributed within $\mathrm{N} 95^{\circ} \mathrm{E} \sim \mathrm{N} 111^{\circ} \mathrm{E}$. The ratio of maximum horizontal principal stress to vertical principal stress (lateral pressure coefficient) is between 1.01 and 1.43. At $-1550 \mathrm{~m}$ level, the maximum horizontal principal stress is $45.84 \mathrm{MPa}$ and the maximum vertical principal stress is $40.95 \mathrm{MPa}$.

The results of in situ stress test show that the horizontal stress of the new main well area of Xincheng gold mine is much greater than the vertical stress, which indicates that the stress formed by the geological structure plays a dominant role in the original rock stress field. At the same time, reference [17] showed that the rock burst tendency of each measuring point was strong rock burst, and a large amount of releasable elastic strain energy was accumulated in the rock volume after excavation. Therefore, in the process of deep construction of the shaft, the damage of shaft surrounding rock will be very common due to the dual effects of high ground stress and excavation disturbance stress. 


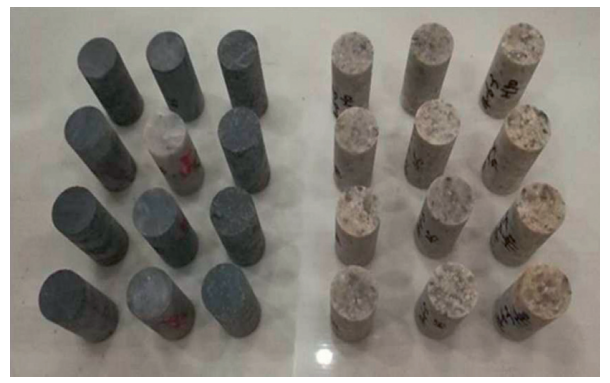

FIGURE 1: Display of some experimental specimens.

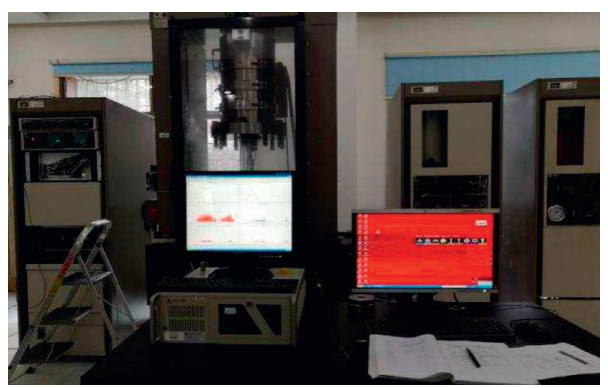

FIgURE 2: Acoustic emission signal acquisition and specimen loading.

TABLE 1: Each measuring point's magnitude and direction of the principal stress in JCK-1 borehole [8].

\begin{tabular}{|c|c|c|c|c|c|}
\hline $\begin{array}{l}\text { Measuring } \\
\text { point } \\
\text { depth }(\mathrm{m})\end{array}$ & $\begin{array}{c}\text { Vertical } \\
\text { principal } \\
\text { stress } \sigma v(\mathrm{MPa}) \\
\end{array}$ & $\begin{array}{c}\text { Self-weight } \\
\text { stress } \sigma(\mathrm{MPa})\end{array}$ & $\begin{array}{c}\text { Maximum } \\
\text { horizontal } \\
\text { principal stress } \sigma H(\mathrm{MPa})\end{array}$ & $\begin{array}{c}\text { Minimum } \\
\text { horizontal } \\
\text { principal stress } \sigma h(\mathrm{MPa})\end{array}$ & $\begin{array}{c}\text { Horizontal } \\
\text { maximum }\end{array}$ \\
\hline-950 & 26.41 & 26.46 & 32.78 & 14.52 & $\mathrm{~N} 103^{\circ} 34^{\prime} \mathrm{E}$ \\
\hline-1050 & 29.22 & 29.16 & 41.83 & 17.18 & $\mathrm{~N} 103^{\circ} 42^{\prime} \mathrm{E}$ \\
\hline-1150 & 33.33 & 31.86 & 35.37 & 16.64 & $\mathrm{~N} 95^{\circ} 43^{\prime} \mathrm{E}$ \\
\hline-1250 & 34.25 & 34.56 & 38.95 & 16.85 & $\mathrm{~N} 110^{\circ} 13^{\prime} \mathrm{E}$ \\
\hline-1350 & 35.98 & 37.26 & 41.23 & 16.44 & $\mathrm{~N} 105^{\circ} 26^{\prime} \mathrm{E}$ \\
\hline-1450 & 40.01 & 39.96 & 40.63 & 14.02 & $\mathrm{~N} 111^{\circ} 20^{\prime} \mathrm{E}$ \\
\hline
\end{tabular}

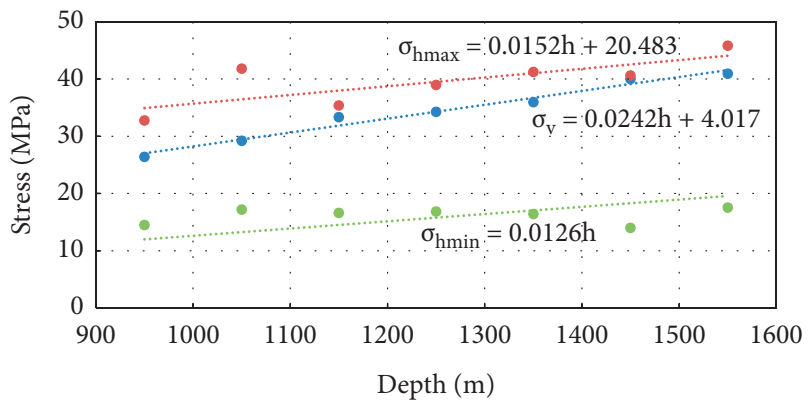

- Vertical principal stress $\sigma_{\mathrm{v}}$

- Maximum horizontal principal stress $\sigma_{\mathrm{hmax}}$

- Minimum horizontal principal stress $\sigma_{\mathrm{hmin}}$

FIGURE 3: Distribution of measured in situ stress field.

3.2. Response Characteristics of Disturbed Stress in Surrounding Rock. Mccreath [18] considered that, after the shaft excavation, the stress distribution of the working face is redistributed. In front of the working face (more than 2.5 times the shaft diameter) is the original rock stress area and there is a high stress concentration area within the range of 2.5 times the diameter of the shaft in front of the working face. The rock mass of the excavation face provides a certain supporting force for the surrounding rock of the shaft, which is $25 \%$ of the original rock stress, so that the surrounding rock of the shaft has enough time for self-stabilization to carry out the supporting work. In the back of the working face about 4.5 times the diameter of the shaft, the supporting force of the working face gradually disappears.

In order to explore the response characteristics of disturbance stress in surrounding rock of shaft excavation, the excavation depth of $-1200 \mathrm{~m}$ was taken as the research object, the model with a side length of $50 \mathrm{~m} \times 50 \mathrm{~m} \times 100 \mathrm{~m}$ was established, and $\mathrm{Flac}^{3 \mathrm{D}}$ numerical simulation software was used to simulate the change process of horizontal stress and strain at $-1200 \mathrm{~m}$ with the change of excavation depth. The simulation process is shown in Figure 4. The physical and mechanical parameters of the model were shown in [17].

The midpoint position in Figure 4 was regarded as $-1200 \mathrm{~m}$. When the excavation reached $-1172 \mathrm{~m}$, the displacement and stress data at $-1200 \mathrm{~m}$ were recorded. The 


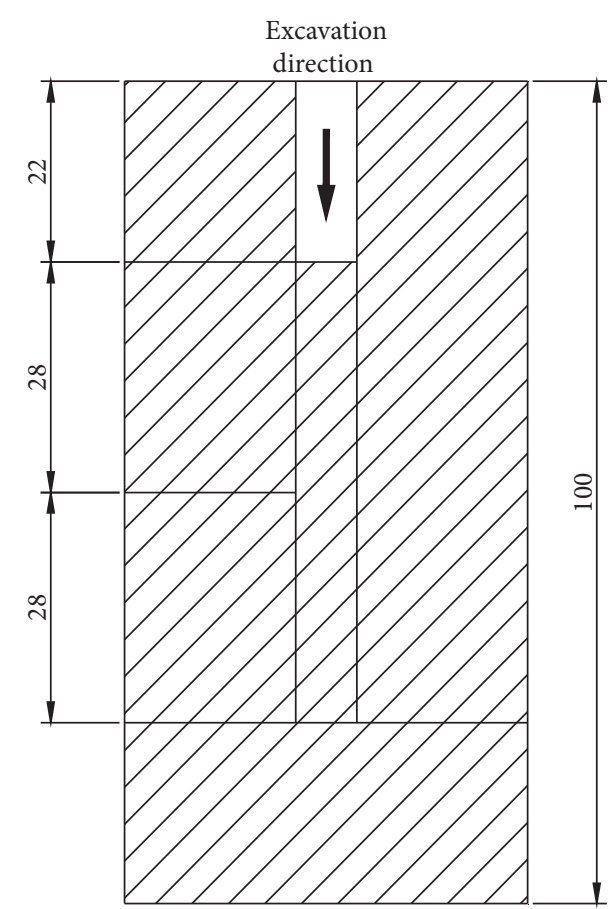

FIGURE 4: Schematic diagram of shaft excavation process analysis.

depth of each excavation was $4 \mathrm{~m}$, a total of 14 times. When the excavation reached $-1228 \mathrm{~m}$, the simulation calculation was completed. The simulation results are shown in Figure 5.

Use fish language to extract the cross-sectional stress and deformation data of the shaft in the $X$-direction after each excavation. The data statistics are shown in Table 2.

The distance in the above table is the difference between the current excavation depth and $-1200 \mathrm{~m}$. The positive number indicates that the excavation has not reached $-1200 \mathrm{~m} \mathrm{level}$, and the negative number indicates that the excavation has exceeded $-1200 \mathrm{~m}$ level. Sort out the data in the above table and draw a line chart. The results are shown in Figure 6.

It can be seen from Figure 6 that, with the progress of excavation, the stress of surrounding rock at $-1200 \mathrm{~m}$ increases slowly at first and then increases rapidly near $-1200 \mathrm{~m}$ level. When the excavation depth exceeds $-1200 \mathrm{~m}$, the stress of surrounding rock in the shaft decreases sharply at $-1200 \mathrm{~m}$ and then slowly decreases until it is unchanged. The first change is at $+20 \mathrm{M}(-1180 \mathrm{~m}$ level $)$; at this time, the radial stress of $x$-axis section at $-1200 \mathrm{~m}$ begins to increase slowly. When the excavation reaches $-24 \mathrm{~m}(-1224 \mathrm{~m}$ level), the radial stress and circumferential stress of $x$-axis section at $-1200 \mathrm{~m}$ do not change with the excavation. Therefore, the influence range of deep shaft excavation disturbance can be estimated to be 6.4 times the shaft radius.

\section{Deformation and Failure Characteristics of Surrounding Rock in Shaft Excavation}

4.1. Failure Form. There are three kinds of failure forms of shaft surrounding rock, which are ear shape, ellipse shape, and butterfly shape. Literature [19] points out that the failure form of shaft surrounding rock affects the radial displacement of excavation boundary of surrounding rock, which in turn affects the deformation law of longitudinal section of the surrounding rock of the shaft. It can be seen that accurately determining the failure form of the surrounding rock of the shaft is of great significance to its stability analysis and control.

Reference [20] summarized the determination method of failure form of surrounding rock of circular excavation structure under different stress ratio and obtained the judgment chart of failure mode of the surrounding rock of circular excavation structure as shown in Figure 7.

According to the judgment rules in Figure 7, combined with the in situ stress test results of the new main shaft area in Xincheng gold mine, the failure form results of the surrounding rock of the new main shaft excavation were obtained as shown in Table 3. It can be seen from Table 3 that the failure form of shaft surrounding rock after shaft excavation was "ear" failure.

4.2. Failure Depth. It is very important for engineering design and construction to determine the failure depth of surrounding rock in shaft excavation. At present, the methods to determine the failure depth of surrounding rock in shaft excavation include theoretical method, numerical simulation method, and engineering analogy method. According to reference [4], the calculation result of theoretical method is too small, while the calculation result of empirical method is too conservative. Therefore, the numerical simulation method is recommended for the depth of failure zone in the process of shaft excavation. By using Phase 2 numerical simulation software and Hoek Brown yield criterion, the distribution pattern and depth of failure zone of surrounding rock at different depths were obtained as shown in Figure 8.

Through the distribution of plastic zone of surrounding rock shown in Figure 5, it is further proved that the surrounding rock of shaft follows the "ear" failure. According to the distribution map of plastic zone of surrounding rock at different depths, the statistical radius of plastic zone is shown in Table 4. It can be seen from Table 4 that, after shaft excavation, the failure depth of surrounding rock of deep shaft was not more than $2.5 \mathrm{~m}$.

\section{Stability Control Method of Surrounding Rock in Shaft Excavation}

5.1. Temporary Support Design. The main function of temporary support is to control the pressure of surrounding rock, and the support pressure of surrounding rock mainly includes the shear expansion pressure and loose surrounding rock pressure. Therefore, the dilatancy pressure can be released in a stable and controllable form by temporary support. At the same time, with the generation and release of the shaft dilatancy pressure, the surrounding rock of the shaft will be damaged and produce radial displacement, which will lead to "loose and sliding." It is necessary to have enough support strength to control the pressure of the loose surrounding rock. 


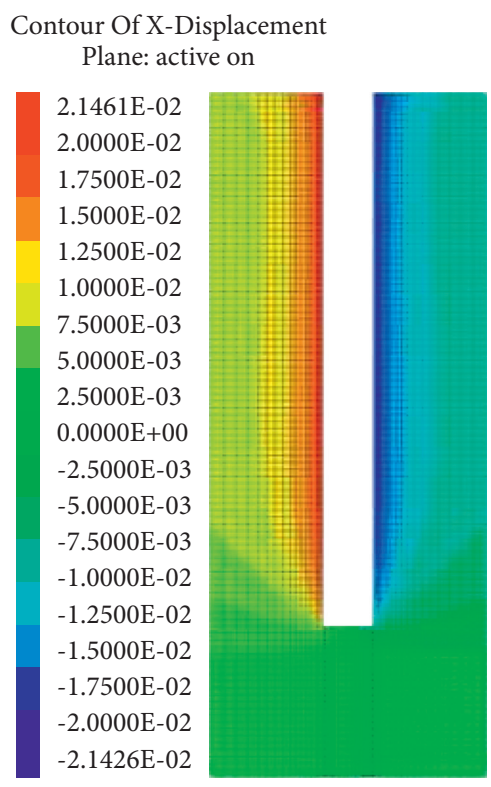

(a)
Contour Of X-Displacement Plane: active on

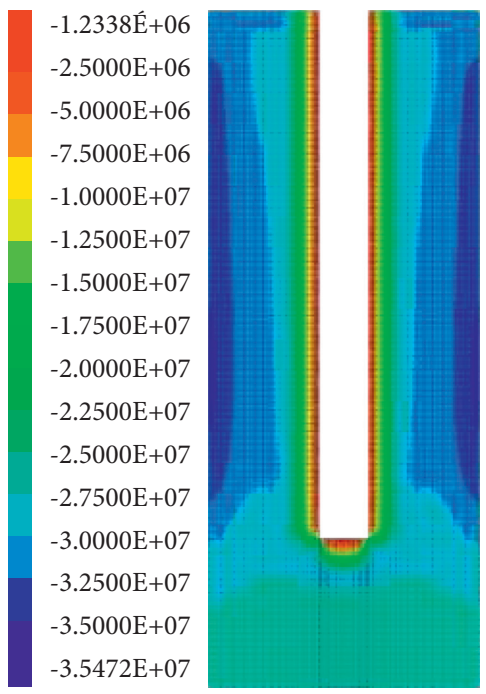

(b)
Contour Of X-Displacement Plane: active on

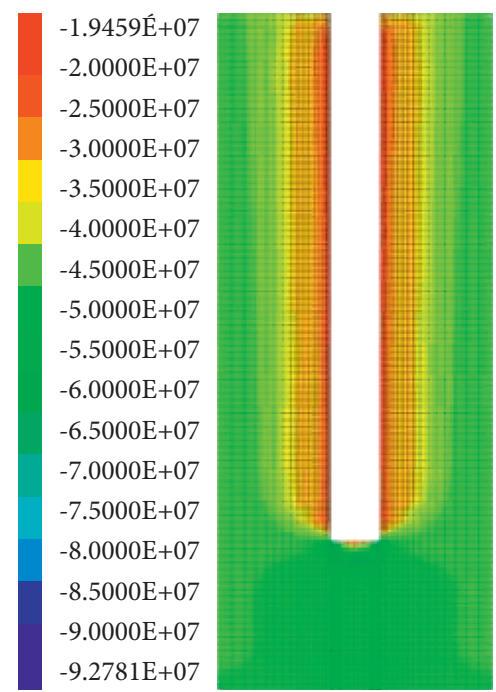

(c)

Figure 5: Results of displacement and stress distribution after shaft excavation. (a) Radial displacement in $x$-axis direction. (b) Maximum principal stress in $X$-direction section. (c) Minimum principal stress in $X$-direction section.

Table 2: Statistical table of stress and deformation data of shaft $X$-direction section after excavation.

\begin{tabular}{lccc}
\hline Distance $(\mathrm{m})$ & Displacement $(\mathrm{mm})$ & Maximum principal stress $(\mathrm{MPa})$ & Minimum principal stress $(\mathrm{MPa})$ \\
\hline 28 & 0.04 & 48.31 & 25.62 \\
24 & 0.05 & 48.38 & 25.63 \\
20 & 0.07 & 48.52 & 25.65 \\
16 & 0.13 & 48.82 & 25.71 \\
12 & 0.27 & 49.40 & 25.88 \\
8 & 0.60 & 50.55 & 26.37 \\
4 & 1.64 & 52.37 & 27.83 \\
0 & 6.15 & 52.28 & 34.32 \\
-4 & 13.77 & 2.50 & 23.11 \\
-8 & 15.95 & 2.54 & 23.53 \\
-12 & 16.98 & 2.52 & 23.35 \\
-16 & 17.56 & 2.50 & 23.00 \\
-20 & 17.91 & 2.49 & 22.67 \\
-24 & 18.12 & 2.47 & 2.39 \\
-28 & 18.24 & 2.46 & 22.18 \\
\hline
\end{tabular}

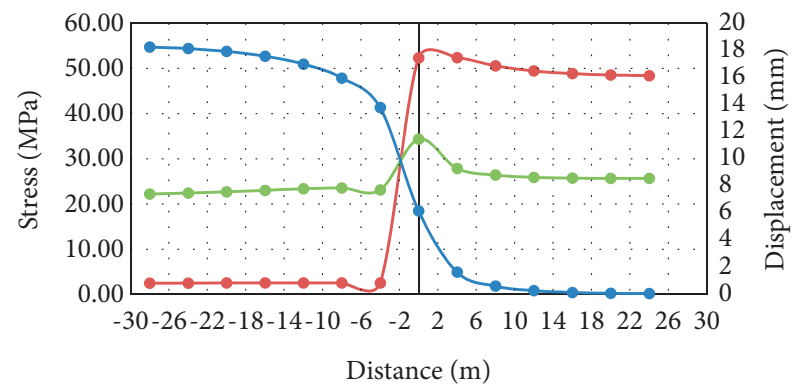

\footnotetext{
$\multimap$ Maximum principal

$\rightarrow$ Minimum principal stress (MPa)

$\rightarrow$ Displacement $(\mathrm{mm})$
}

Figure 6: Stress and deformation curve of $X$-direction section at $-1200 \mathrm{~m}$ of shaft longitudinal section after excavation.
Therefore, the temporary support form of surrounding rock of shaft is anchor net beam support.

According to the engineering analogy [21] and the failure form and depth of the surrounding rock of the shaft, it was decided to adopt the pipe seam bolt with the length of $2.5 \mathrm{~m}$, the diameter of $20 \mathrm{~mm}$, and the spacing of $1.5 \mathrm{~m}$. The metal mesh was 8 \# wire diamond mesh. Double bars were welded with $\varphi 8$ or $\varphi 10$ steel bars, with an interval of $80 \mathrm{~mm}$ and a length of $3 \mathrm{~m}$. The above temporary support structure can be constructed after shaft excavation. The effect of temporary on-site support is shown in Figure 9.

5.2. Design of Permanent Concrete Support. A concrete shaft with a thickness of $300 \mathrm{~mm}$ can meet the support requirements of various rock conditions [22]. In order to ensure the 


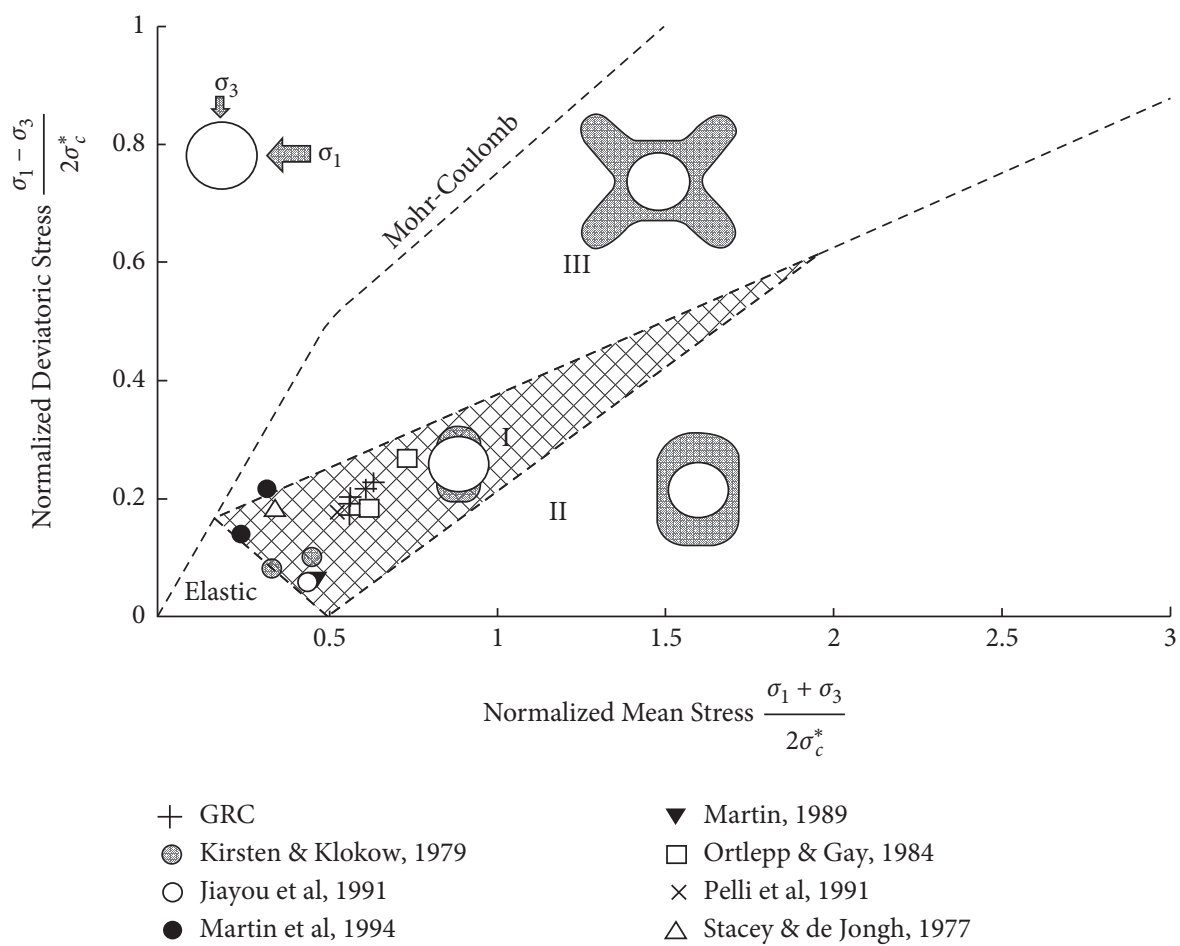

FiguRE 7: Determination diagram of failure mode of surrounding rock of circular excavation structure.

TABLE 3: Normalization treatment of surrounding rock stress at different depths.

\begin{tabular}{lcccccc}
\hline Position $(\mathrm{m})$ & $\sigma_{1}(\mathrm{MPa})$ & $\sigma_{3}(\mathrm{MPa})$ & $\sigma_{\mathrm{c}}(\mathrm{MPa})$ & $\begin{array}{c}\text { Normalized value } \\
\text { of deviatoric stress }(\mathrm{MPa})\end{array}$ & $\begin{array}{c}\text { Normalized value } \\
\text { of average stress }(\mathrm{MPa})\end{array}$ & $\begin{array}{c}\text { Judgment } \\
\text { result }\end{array}$ \\
\hline-950 & 38.481 & 20.586 & 102.5 & 0.09 & 0.29 & 0.32 \\
-1050 & 41.981 & 22.686 & 102.5 & 0.09 & 0.34 & $\mathrm{I}$ \\
-1150 & 45.481 & 24.786 & 102.5 & 0.10 & 0.37 & $\mathrm{I}$ \\
-1250 & 48.981 & 26.886 & 102.5 & 0.11 & 0.40 & $\mathrm{I}$ \\
-1350 & 52.481 & 28.986 & 102.5 & 0.11 & 0.42 \\
-1450 & 55.981 & 31.086 & 102.5 & 0.12 & $\mathrm{I}$ \\
\hline
\end{tabular}

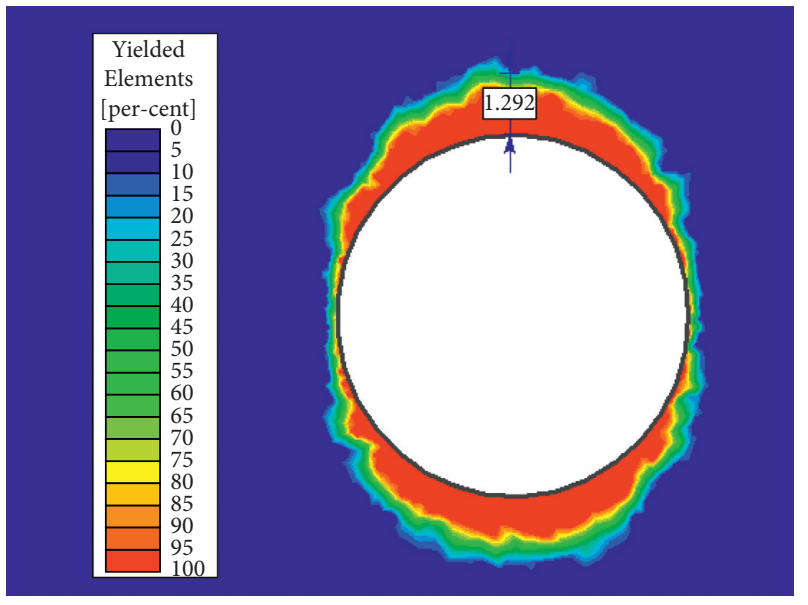

(a)

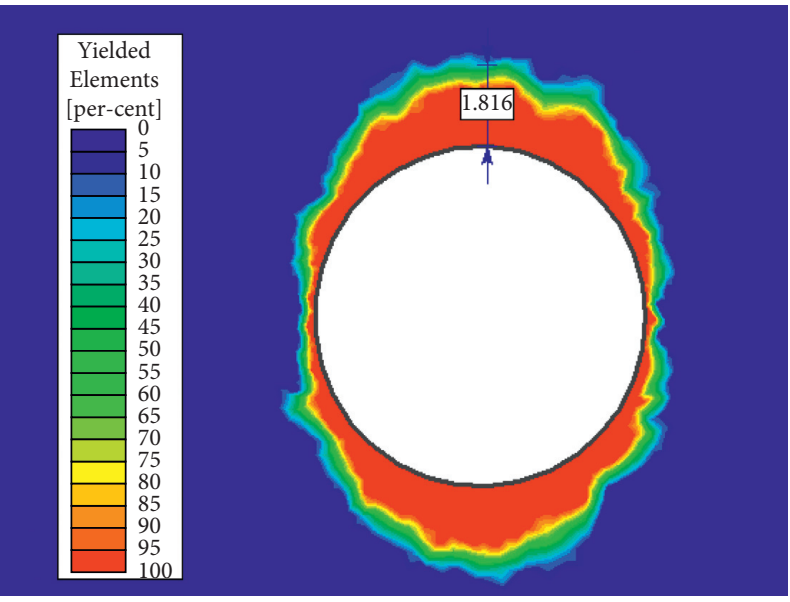

(b)

Figure 8: Continued. 


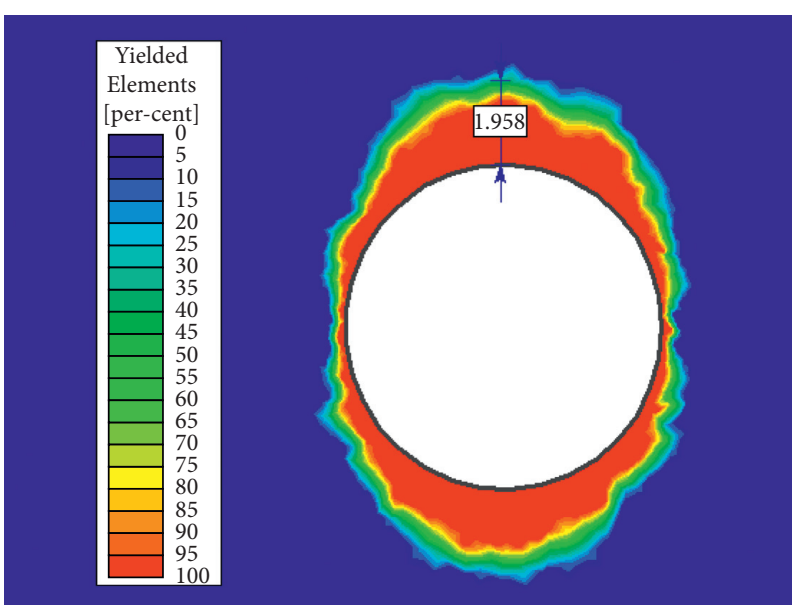

(c)

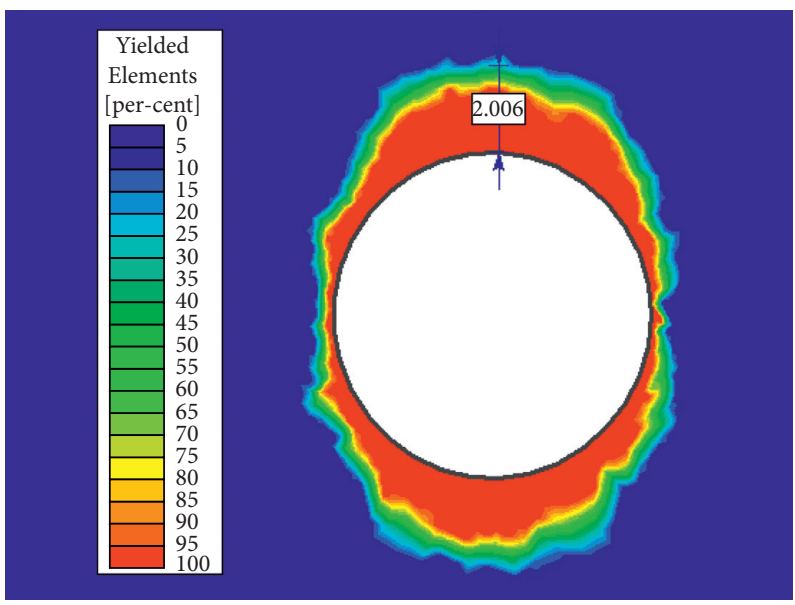

(e)

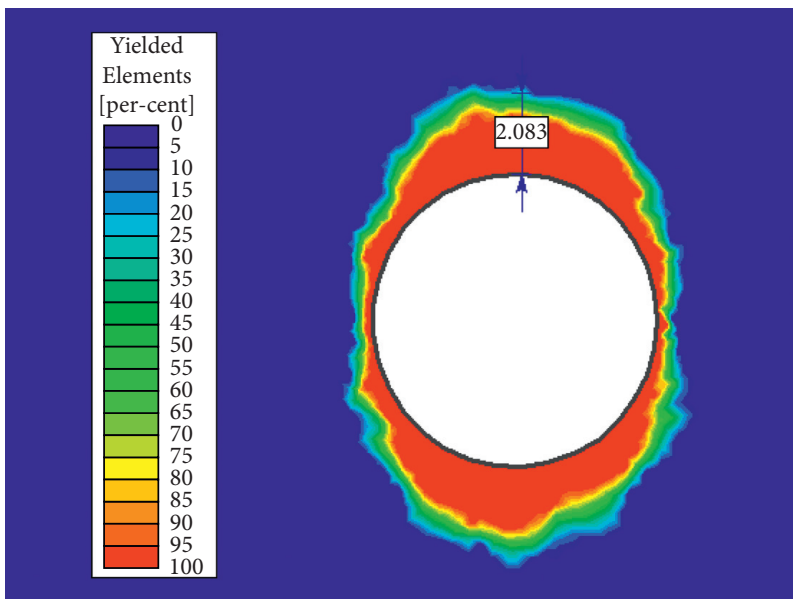

(g)

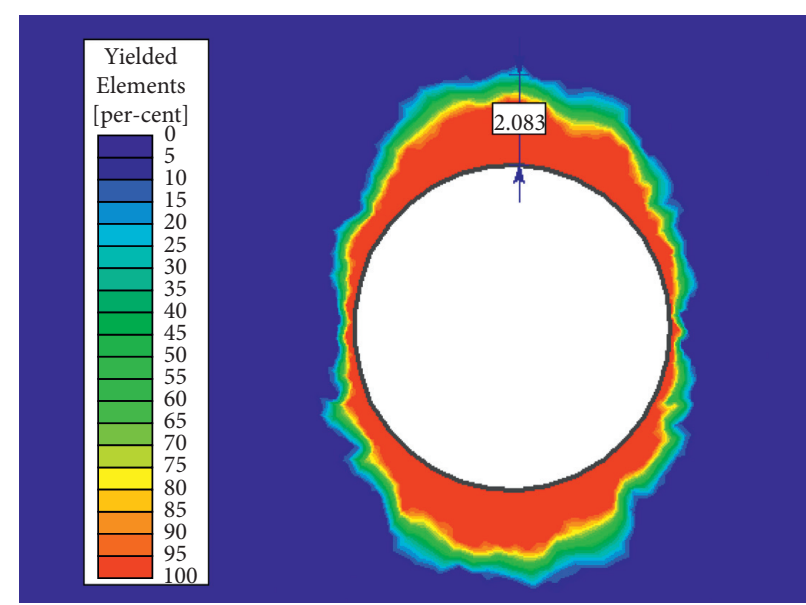

(d)

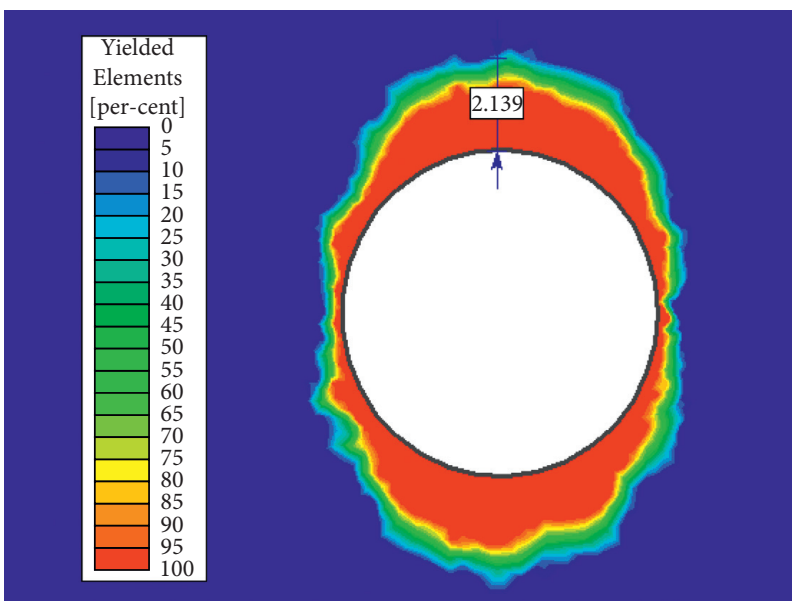

(f)

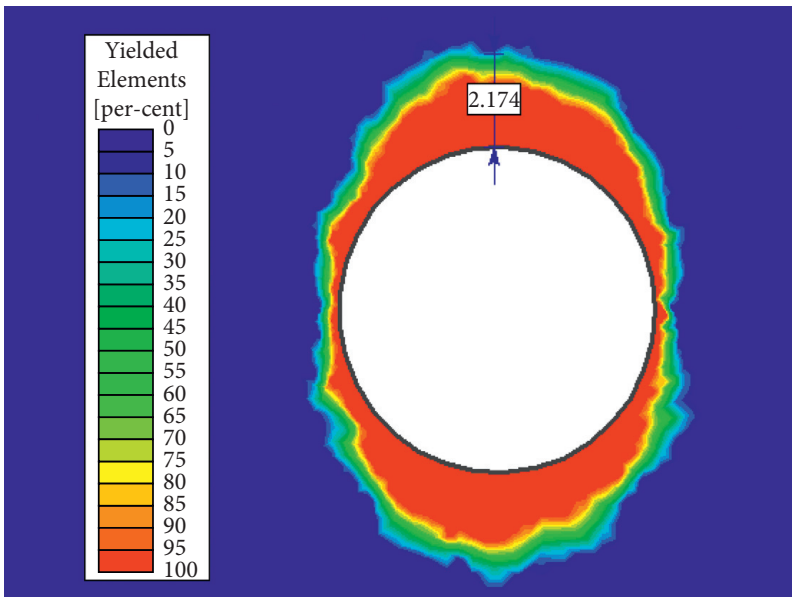

(h)

FIGURE 8: Distribution of plastic zone of surrounding rock at different depth of shaft: (a) $-930 \mathrm{~m} \sim-972 \mathrm{~m}$, (b) $-972 \mathrm{~m} \sim-1050 \mathrm{~m}$, (c) $-1050 \mathrm{~m} \sim-1073 \mathrm{~m}$, (d) $-1073 \mathrm{~m} \sim-1102 \mathrm{~m}$, (e) $-1102 \mathrm{~m} \sim-1153 \mathrm{~m}$, (f) $-1153 \mathrm{~m} \sim-1207 \mathrm{~m}, \quad$ (g) $-1207 \mathrm{~m} \sim-1250 \mathrm{~m}$, and (h) $-1250 \mathrm{~m} \sim-1271 \mathrm{~m}$.

stability of deep surrounding rock of new main shaft of Xincheng gold mine, it was decided to use concrete with a thickness of $400 \mathrm{~mm}$ for permanent support, and the concrete grade was C25. Referring to the experience of South Africa and other foreign countries, the corresponding time was about 3 days when the diameter of the shaft without support span was 2-3 times. Therefore, in order to fully release the pressure of the surrounding rock of the shaft, the temporary support span of the new main shaft of Xincheng gold mine was determined to be $12 \mathrm{~m}$, which was a three-day 
TABLE 4: Radius of plastic zone of surrounding rock after shaft excavation.

\begin{tabular}{lr}
\hline Shaft depth $(\mathrm{m})$ & Radius of plastic zone (m) \\
\hline$-930 \mathrm{~m} \sim-972 \mathrm{~m}$ & 1.29 \\
$-972 \mathrm{~m} \sim-1050 \mathrm{~m}$ & 1.82 \\
$-1050 \mathrm{~m} \sim-1073 \mathrm{~m}$ & 1.96 \\
$-1073 \mathrm{~m} \sim-1102 \mathrm{~m}$ & 2.08 \\
$-1102 \mathrm{~m} \sim-1153 \mathrm{~m}$ & 2.01 \\
$-1153 \mathrm{~m} \sim-1207 \mathrm{~m}$ & 2.14 \\
$-1207 \mathrm{~m} \sim-1250 \mathrm{~m}$ & 2.08 \\
$-1250 \mathrm{~m} \sim-1271 \mathrm{~m}$ & 2.17 \\
\hline
\end{tabular}

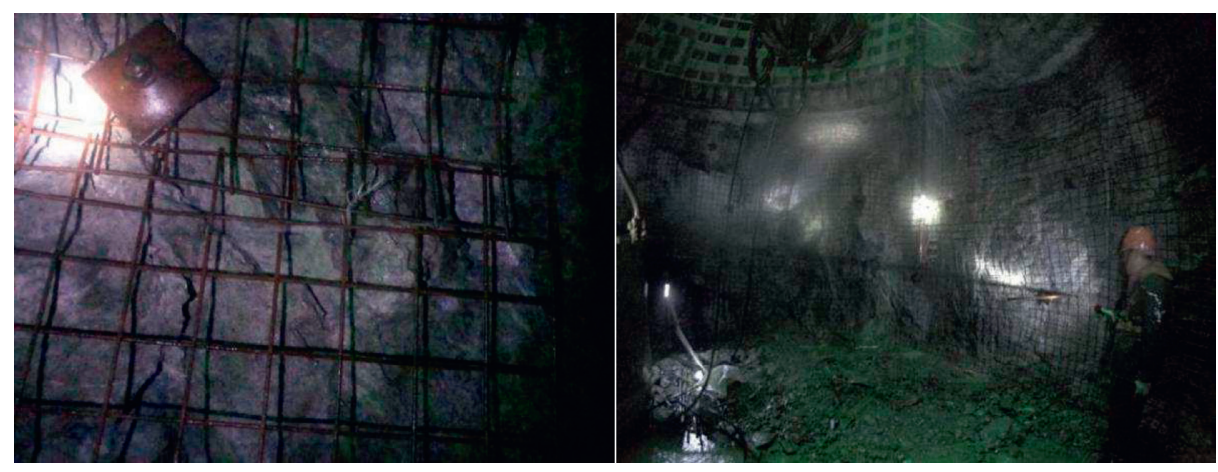

Figure 9: Effect of temporary on-site support.

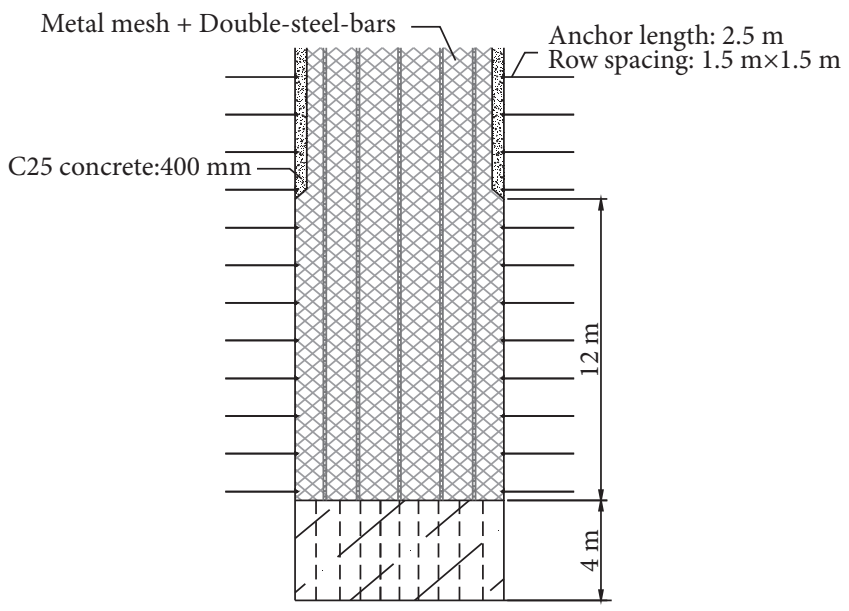

(a)

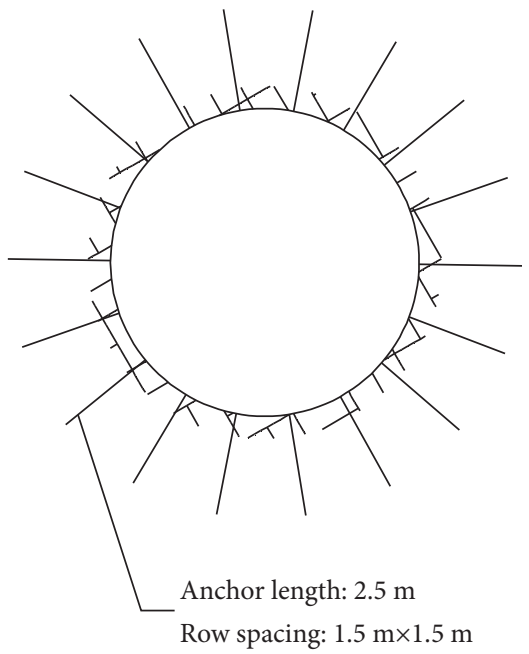

(b)

FIGURE 10: Support design of new main shaft $-930 \mathrm{~m} \sim-1271 \mathrm{~m}$. (a) Schematic diagram of shaft longitudinal section support design. (b) Schematic diagram of shaft transverse section support design.

excavation cycle. This construction method can be used for the subsequent construction of concrete shaft lining in the state of "no pressure bearing or slow low pressure bearing" and can avoid the influence of excavation disturbance on concrete support as far as possible.

Based on the above shaft support methods, the schematic diagram of the deep shaft support design of the Xincheng gold mine is shown in Figure 10.
The permanent support effect of on-site concrete is shown in Figure 11. Based on the improved construction technology of "three-excavation and one-masonry," the use of C25 concrete with a thickness of $400 \mathrm{~mm}$ for permanent support has a good on-site construction effect, which can meet the stability of shaft surrounding rock and lining under the condition of high stress in the deep of new main shaft. 

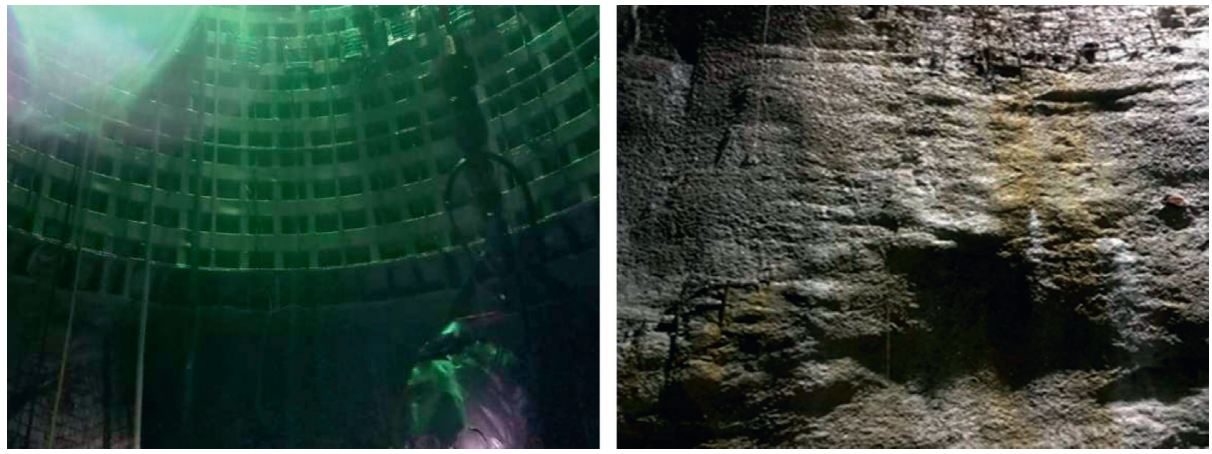

Figure 11: Permanent concrete on-site support effect.

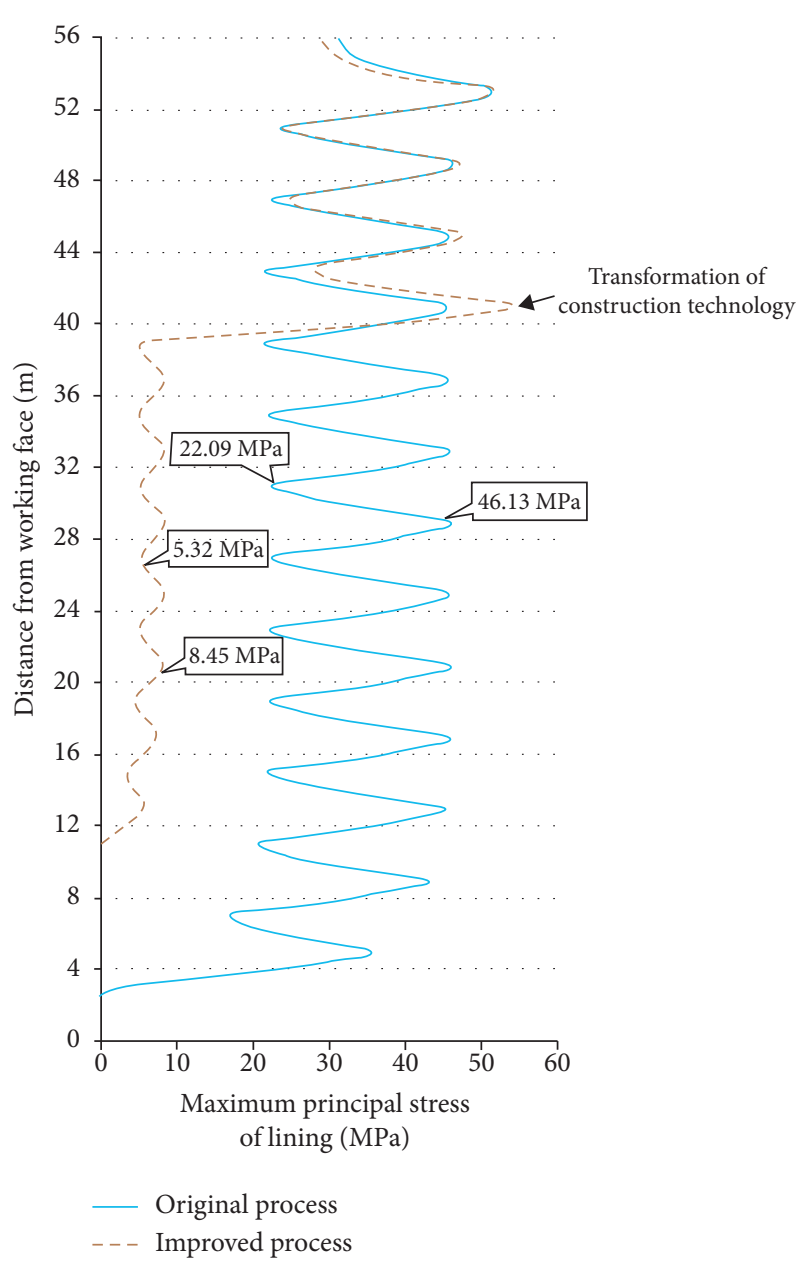

Figure 12: Maximum principal stress curve of lining.

\subsection{Rationality Verification of Construction Technology.} Because the temporary span of surrounding rock was determined to be $12 \mathrm{~m}$, the construction technology of "threeexcavation and one-masonry" was adopted below $-930 \mathrm{~m}$. In order to verify the rationality of the construction technology, through numerical simulation (only the surrounding rock with a height of $76 \mathrm{~m}$ above $-1276 \mathrm{~m}$ was selected as the calculation area), the maximum principal stress curves of lining with two kinds of excavation and support technology were obtained as shown in Figure 12. It can be seen from the figure that the average fluctuation range of the maximum principal stress of the original process was $23.7 \mathrm{MPa}$, while the fluctuation range of the improved process was $3.5 \mathrm{MPa}$, which indicates that the improved process can make the stress in the lining more uniform. The compressive safety factor of lining can be calculated by the following formula:

$$
K=\frac{\sigma_{c c}}{\sigma_{\max }}
$$

where $\sigma_{c c}$ was taken as the axial compressive strength of C25 concrete in the shaft lining of $16.7 \mathrm{MPa}$, and $\sigma_{\max }$ was the maximum principal stress in the lining.

The compressive safety coefficient of the original process lining was 0.36 calculated from formula (1), which indicates that plastic failure will occur in the original process lining. The improved pressure safety factor of lining was 1.98 , which meets the safety requirements.

\section{Conclusion}

(1) The deep surrounding rock of the new main shaft in Xincheng gold mine is mainly horizontal stress, and the surrounding rock of the shaft wall has a strong rock burst tendency after shaft excavation, and the influence range of the deep excavation disturbance is 6.4 times the shaft radius. Therefore, bolt mesh beam temporary support measures shall be adopted to fully release the surrounding rock stress in the area prone to strong rock burst before permanent support, so as to reduce the impact of surrounding rock stress and excavation disturbance stress on the stability of shaft wall surrounding rock.

(2) For the construction of large section and ultradeep shaft, the failure mode and failure depth of surrounding rock can be determined by combining the failure mode judgment chart of surrounding rock of circular excavation structure and numerical simulation. The failure shape of surrounding rock of deep shaft excavation in Xincheng gold mine is "ear" failure, and the failure depth is no more than $2.5 \mathrm{~m}$.

(3) According to the characteristics of high crustal stress and strong rock burst tendency of large section and ultradeep shaft, in order to fully release the pressure of shaft surrounding rock and minimize the impact 
of excavation disturbance stress on the stability of shaft surrounding rock, the support construction technology of "no pressure or slow low pressure" can be adopted. After the temporary support of the new main shaft of Xincheng gold mine adopts the construction technology of "three-excavation and one-masonry," the compressive safety factor of permanent support is increased from 0.36 to 1.98 , and the on-site support construction effect is significantly improved.

\section{Data Availability}

The data that support the findings of this study are available from the corresponding author upon reasonable request.

\section{Conflicts of Interest}

The authors declare that they have no conflicts of interest.

\section{References}

[1] L. Cheng, J. Wang, J. Zhao, and H. Kuikui, "Surrounding rock control and supporting optimization of Sishanling shaft well," Metal Mine, vol. 505, no. 7, pp. 74-77, 2018.

[2] Z. Yao, H. Cheng, and Z. Yang, "Failure mechanism, analysis and repair of mine ventilation shaft lining in Qujiang," Coal Science and Technology, vol. 30, no. 6, pp. 12-14, 2002.

[3] Y. Xu, Z. Zhang, and J. Jiang, "Failure mechanism and instability analysis of surrouding rock in deep mine," Chinese Journal of Underground Space and Engineering, vol. 3, no. 7, pp. 1212-1215, 2007.

[4] Y. Zhang, Q. Xue, and Z. Shi, "Damage form research of shaft sidewall under local load," Journal of Yanshan University, vol. 33, no. 6, pp. 528-534, 2009.

[5] X. Liu, H. Liu, W. Zhu, L. Li, and H. Zhang, "Preliminary study on the determination of shaft pillar based on the ratio of horizontal tectonic stress," Metal Mine, vol. 523, no. 1, pp. 122-129, 2020.

[6] S. Fu, X. Zhang, and H. Li, "Characteristics and prevention and control measures of rock burst in excavation of ultra-deep shaft," Journal of Safety Science and Technology, vol. 12, no. 12, pp. 48-52, 2016.

[7] S. Cao, F. Luo, C. Cheng, G. Li, and P. Guo, "Surrouding rock control of shaft in water enriched fault fracture zone," Chinese Journal of Rock Mechanics and Engineering, vol. 33, no. 8, pp. 1536-1545, 2014.

[8] H. Liu, X. Wang, and L. Cheng, "Multi-index prediction of rock burst tendency in deep shaft excavation," Metal Mine, vol. 522, no. 12, pp. 50-55, 2019.

[9] Z. Song, T. Frühwirt, and H. Konietzky, "Fatigue characteristics of concrete subjected to indirect cyclic tensile loading: insights from deformation behavior, acoustic emissions and ultrasonic wave propagation," Construction and Building Materials, vol. 302, Article ID 124386, 2021.

[10] Z. Song, Y. Wang, H. Konietzky, and X. Cai, "Mechanical behavior of marble exposed to freeze-thaw-fatigue loading," International Journal of Rock Mechanics and Mining Sciences, vol. 138, Article ID 104648, 2021.

[11] Z. Song, H. Konietzky, and X. Cai, "Modulus degradation of concrete exposed to compressive fatigue loading: insights from lab testing," Structural Engineering \& Mechanics, vol. 78, pp. 281-296, 2021.
[12] Y. Ju, H. Liu, G. Wang et al., "Mechanical mechanism of reinforcing shaft-wall with pressure release and casing-wall method and its engineering application," Chinese Journal of Rock Mechanics and Engineering, vol. 22, no. 5, pp. 773-777, 2003.

[13] X. Zhou, Q. Hu, C. Ma, and Z. He, "Comparing research on effect of enclosure rock to enhance bearing capacity of shaft lining," Journal of China Coal Society, vol. 37, no. Supplement 1, pp. 26-32, 2012.

[14] H. Li and X. Wang, "Deformation and failure law and control technology of surrounding rock in deep shaft," Metal Mine, vol. 533, no. 11, pp. 11-18, 2020.

[15] C. Sun, X. Zhang, and J. Zhang, "Stability analysis of vertical shaft surrounding rock and supporting system in deep fault fracture," Journal of China Coal Society, vol. 38, no. 4, pp. 587-594, 2013.

[16] Z. Bian, "Complete set of construction technology for large diameter and super depth vertical shaft," Mine Construction Technology, vol. 39, no. 5, pp. 1-6, 2018.

[17] H. Liu, Z. Tan, X. Wang, G. Li, and L. Cheng, "Prediction of rock burst risk in deep shaft excavation of Xincheng gold mine," Journal of China University of Mining \& Technology, vol. 49, no. 2, pp. 296-304, 2020.

[18] D. R. Mccreath, Analysis of Formation Pressures on Tunnel and Shaft linings, University of Alberta, Edmonton, Canada, 1980.

[19] N. Vlachopoulos and M. S. Diederichs, "Improved longitudinal displacement profiles for convergence confinement analysis of deep tunnels," Rock Mechanics and Rock Engineering, vol. 42, no. 2, pp. 131-146, 2009.

[20] X. Zhao, Mining Induced Ground Pressure and Control in Deep Hard Rock deposit, Metallurgical Industry Press, Beijing, China, 2019.

[21] N. Barton, R. Lien, and J. Lunde, "Engineering classification of rock masses for the design of tunnel support," Rock Mechanics, vol. 6, no. 4, pp. 189-236, 1974.

[22] G. W. Holl and E. G. Fairon, "A review of some aspects of shaft design," Journal of the South African Institute of Mining and Metallurgy, vol. 73, no. 10, pp. 309-324, 1973. 